\title{
OPEN Effect of minerals and heavy metals in sand samples of Ponnai river, Tamil Nadu, India
}

\author{
A. Chandrasekaran $\bowtie$, C. K. Senthil Kumar, V. Sathish, S. Manigandan \& A. Tamilarasi
}

River sand samples have been collected from Ponnai river, Tamil Nadu, India for characterization of minerals and heavy metals by different spectroscopic techniques. Initially, the samples were subjected by Fourier Transform-Infra Red (FT-IR) spectroscopic technique and infra-red absorption bands values are observed in the range of $515-520,695-700,775-780 \mathrm{~cm}^{-1}$ which shows the presence of quartz in all the samples. Similarly, infra-red peaks were absorbed for feldspar, kaolinite, calcite, gibbsite and organic carbon and confirmed by X-Ray diffraction (XRD) technique. Additionally, zircon, aragonite, magnetite and kyanite minerals were identified in the samples using only the XRD method. The concentration of heavy metals such as $\mathrm{Pb}, \mathrm{Cr}, \mathrm{Zn}, \mathrm{Ni}, \mathrm{Hg}, \mathrm{As}, \mathrm{Mn}, \mathrm{Cu}$ has been determined by flame atomic absorption spectrometry (FAAS). An average metal concentration measured in $\mathrm{mg} \mathrm{kg}^{-1}$ were: $\mathrm{Pb} 0.12$, As 0.15, $\mathrm{Hg} 0.13, \mathrm{Cu} 2.80, \mathrm{Zn} 10.15 \mathrm{Cr} 12.70$, Ni 2.86 and $\mathrm{Mn} 104.94$ and hence found in the order of $\mathrm{Mn}>\mathrm{Cr}>\mathrm{Zn}>\mathrm{Ni}>\mathrm{Cu}>\mathrm{As}>\mathrm{Hg}>\mathrm{Pb}$. These average values do not exceed the world average value and hence potentially do not affect the quality of sand in the river. In addition to that, presences of heavy metals are confirmed by scanning electron microscope equipped with energy dispersive X-ray spectrometry (SEM/EDS) analysis. In order to understand the possible natural and anthropogenic sources of heavy metals, multivariate statistical techniques such as Pearson correlation, principal component and cluster analysis were performed. Results obtained from the statistical techniques were good agreement with each other.

Sand is a naturally occurring granular material composed of finely divided rock and mineral particles and formed by the weathering of rocks. The most common constituent of sand is silica (Silicon dioxide, or $\mathrm{SiO}_{2}$ ), usually in the form of quartz. Other minerals such as feldspar, clay and carbonate minerals also dominated in the sand and sediments. FT-IR and XRD are powerful, efficient and accurate measurement techniques for mineral analysis ${ }^{1,2}$. In addition, many researchers have reported the mineral content of river sands throughout the world as well as in various parts of India ${ }^{3-7}$.

Rivers are important for water source and supports the both a way of life and livelihood for huge number of people, providing income via fishing and aquaculture. Due to industrialization and urban development, environment has been polluted through both natural and anthropogenic activities. These activities resulted in increasing quantities of contaminants into the lakes, rivers, reservoirs, and wetlands ${ }^{8}$. Consequently, a variety of environmental problems have cropped up and toxic metal pollution has become a major issue, especially in urban air, soils and sediments ${ }^{9-11}$.

River pollution is an important issue in the world which requires ongoing evaluation and revision. River pollution occurs, when unwanted materials enter into the river, changes the quality of river and anthropogenic activities such as discharge of industrial and domestic wastewater, the dumbing of sewage, washing of motor vehicles, agricultural activities, firing and mining makes the adverse effects in the river area. It also affects the aquatic animals, micro-organisms and human health ${ }^{12,13}$. These anthropogenic activities enhance the level of heavy metals in the river sediments and sand samples. Heavy metal (HM) pollution is inflicting rivers worldwide ${ }^{14,15}$, especially in developing countries ${ }^{16,17}$. As an important component in riverine ecosystems, sediment serves as both a sink and a source of heavy metals ${ }^{18,19}$. Most heavy metals quickly deposit into the sediment after entering rivers, and are much more concentrated in the sediment than in the water body of river systems ${ }^{20,21}$.

In recent decades, several analytical instrumental techniques can be employed for the determination of heavy metals. For example, the heavy metals $\mathrm{Cd}, \mathrm{Pb}, \mathrm{Hg}$ and $\mathrm{Cr}$ can be determined by Atomic absorption spectrometry (AAS), Energy-Dispersive X-ray Fluorescence (EDXRF) spectrometry, Inductively coupled plasma-Optical emission Spectrometry (ICP-OES) or Inductively Coupled Plasma-Mass-Spectrometry (ICP-MS) ${ }^{22,23}$. Hexavalent 


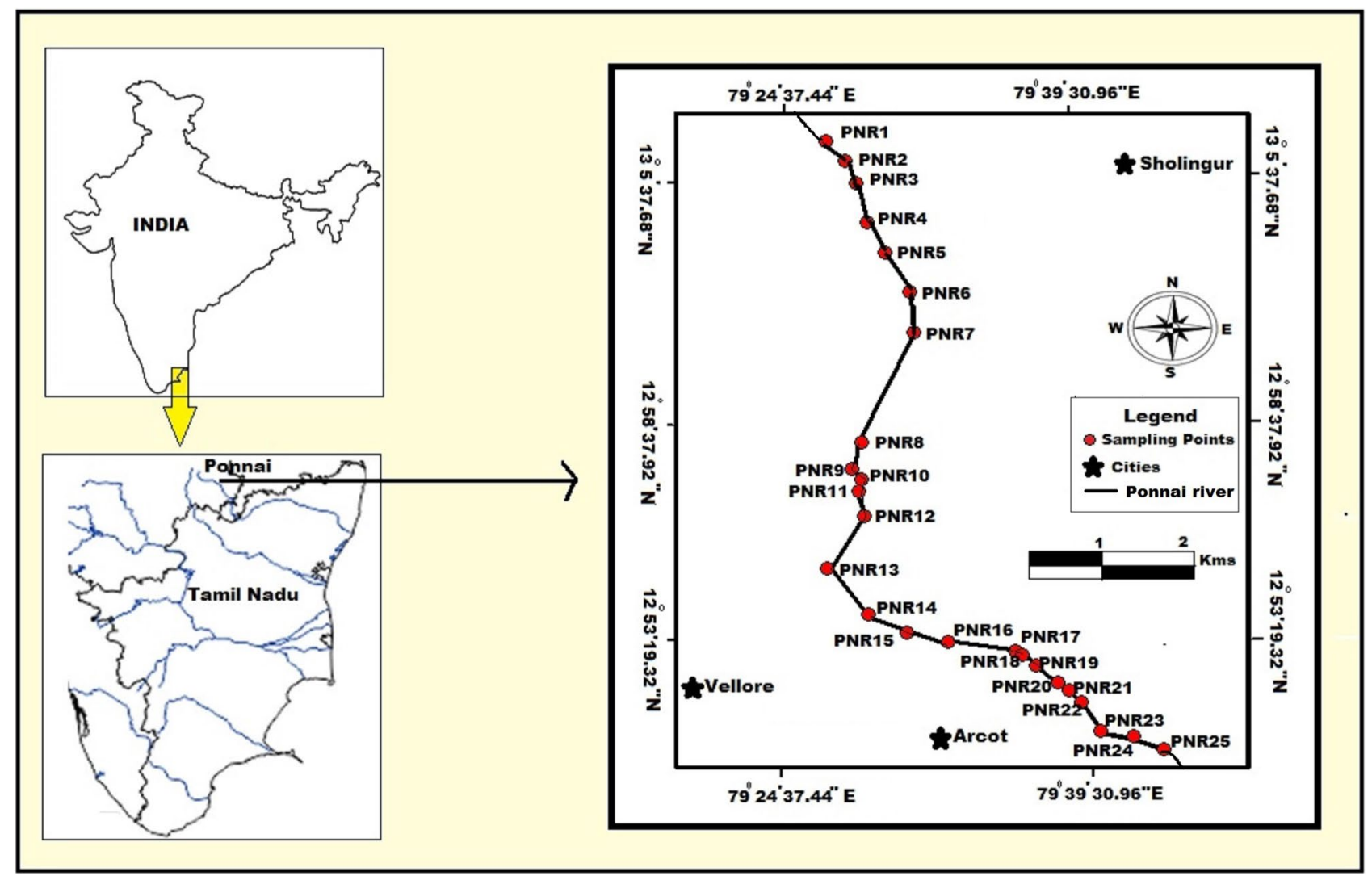

Figure 1. Sampling locations in Ponnai River, Tamilnadu (Map drawn using the software "MapInfo Professional version 8.5”).

chromium can be determined by UV-Vis spectrometer ${ }^{24,25}$. On the other hand, XRF can also be used for quantification of heavy metals and total bromine ${ }^{26}$. In this work, heavy metals such as $\mathrm{Pb}, \mathrm{Cr}, \mathrm{Zn}, \mathrm{Ni}, \mathrm{Hg}, \mathrm{As}, \mathrm{Mn}, \mathrm{Cu}$ is determined by Flame Atomic Absorption spectroscopic technique (FAAS) since it has high precision and rapid process in elemental analysis ${ }^{27}$. The detection limit for AAS is up to $0.1 \mu \mathrm{g} \mathrm{kg}{ }^{-1}$ under optimum test conditions.

With its high spatial resolution, large depth field, and simple specimen preparation, scanning electron microscopes with energy dispersive X-ray spectrometry (SEM/EDS) are a suitable technique most commonly used in soil, sediment and rock characterization. The SEM/EDS mapping has been integrated to provide a new perspective of the dynamic biogeochemistry processes. Scanning electron microscopy (SEM) was used to examine the morphology of particles and aggregates in sediments of Ponnai river, Tamil Nadu. Energy-dispersive X-ray spectrometry (EDS) was also used to analyze the elemental composition and distribution, with a focus on heavy metals.

A multivariate statistical method such as the principal component analysis (PCA) and cluster analysis (CA) is a powerful tool for evaluating pollution levels among samples ${ }^{28,29}$. The PCA method has been widely applied in geochemical applications to identify the sources of pollution and to distinguish natural pollution from anthropogenic pollution ${ }^{30,31}$. When combined with PCA, CA serves as a check for results and allows for the grouping of individuals parameters and variables ${ }^{32-37}$.

Based on the above discussions, the main objectives of the present work is to (i) identify the primary (quartz $\left(\mathrm{SiO}_{2}\right)$, and feldspar $\left.(\mathrm{Na}, \mathrm{K}) \mathrm{AlSi}_{3} \mathrm{O}_{8}\right)$ and secondary minerals (clay, carbonate and Gibbsite minerals) in the sand samples using FT-IR spectroscopic technique (ii) confirm the identified minerals by XRD technique in sand samples (iii) to determine the concentration of heavy metals such as $\mathrm{As}, \mathrm{Hg}, \mathrm{Pb}, \mathrm{Cu}, \mathrm{Zn}, \mathrm{Ni}, \mathrm{Cr}$ and $\mathrm{Mn}$ in sand samples using Atomic absorption spectrometry (iv) obtained results of heavy metals are compared with toxic reference values given by United State Environment Protection Agency (USEPA), average shale value (ASV) and TRV (toxicity reference value), (v) to confirm the presence of heavy metals using scanning electron microscope equipped with energy dispersive X-ray spectrometry (SEM/EDS) and (vi) to find the possible pollution sources of heavy metals whether natural or anthropogenic using multivariate statistical techniques.

\section{Geology of the study area}

Geologically, the Ponnai river flows from the North direction and ends with the East direction and sampling points are depicted in Fig. 1. It passes along the hard rock formation of Archean crystalline and metamorphic complex that overlaid by sedimentary formation. The area underwent numerous tectonic and magmatic activities during the pre-Cambrian period. Fissile hornblende biotite gneiss is the oldest rock in the study area. Charnockites are coarse grained and their color is bluish dark to grey and it occurred a few sq.km where the Ponnai 


\begin{tabular}{|c|c|c|c|c|}
\hline \multirow[b]{2}{*}{ S. no. } & \multirow[b]{2}{*}{ Sample ID } & \multicolumn{2}{|c|}{ Geographical coordinates } & \multirow[b]{2}{*}{ Location name } \\
\hline & & \begin{tabular}{|l|} 
Longitude \\
\end{tabular} & Latitude & \\
\hline 1 & PNR1 & $79^{\circ} 15^{\prime} 17.964^{\prime \prime} \mathrm{E}$ & $13^{\circ} 7^{\prime} 17.796^{\prime \prime} \mathrm{N}$ & Ponnai \\
\hline 2 & PNR2 & $79^{\circ} 15^{\prime} 45.936^{\prime \prime} \mathrm{E}$ & $13^{\circ} 6^{\prime} 48.096^{\prime \prime} \mathrm{N}$ & Dhanalakshmai Nagar \\
\hline 3 & PNR3 & $79^{\circ} 16^{\prime} 1.596^{\prime \prime} \mathrm{E}$ & $13^{\circ} 6^{\prime} 16.452^{\prime \prime} \mathrm{N}$ & Vasur \\
\hline 4 & PNR4 & $79^{\circ} 16^{\prime} 17.076^{\prime \prime} \mathrm{E}$ & $13^{\circ} 5^{\prime} 18.06^{\prime \prime} \mathrm{N}$ & Anaicut \\
\hline 5 & PNR5 & $79^{\circ} 16^{\prime} 43.824^{\prime \prime} \mathrm{E}$ & $13^{\circ} 4^{\prime} 34.86^{\prime \prime} \mathrm{N}$ & Palleri \\
\hline 6 & PNR6 & $79^{\circ} 17^{\prime} 19.104^{\prime \prime} \mathrm{E}$ & $13^{\circ} 3^{\prime} 37.368^{\prime \prime} \mathrm{N}$ & Kondakuppam \\
\hline 7 & PNR7 & $79^{\circ} 17^{\prime} 24.756^{\prime \prime} \mathrm{E}$ & $13^{\circ} 2^{\prime} 38.148^{\prime \prime} \mathrm{N}$ & Veppalai \\
\hline 8 & PNR8 & $79^{\circ} 16^{\prime} 9.156^{\prime \prime} \mathrm{E}$ & $12^{\circ} 59^{\prime} 55.86^{\prime \prime} \mathrm{N}$ & Ekambaranellur \\
\hline 9 & PNR9 & $79^{\circ} 15^{\prime} 56.808^{\prime \prime} \mathrm{E}$ & $12^{\circ} 59^{\prime} 17.988^{\prime \prime} \mathrm{N}$ & Thiruvalam \\
\hline 10 & PNR10 & $79^{\circ} 16^{\prime} 8.724^{\prime \prime} \mathrm{E}$ & $12^{\circ} 59^{\prime} 2.76^{\prime \prime} \mathrm{N}$ & Nellikuppam \\
\hline 11 & PNR11 & $79^{\circ} 16^{\prime} 5.592^{\prime \prime} \mathrm{E}$ & $12^{\circ} 58^{\prime} 45.516^{\prime \prime} \mathrm{N}$ & Sikarajapuram \\
\hline 12 & PNR12 & $79^{\circ} 16^{\prime} 13.332^{\prime \prime} \mathrm{E}$ & $12^{\circ} 58^{\prime} 8.292^{\prime \prime} \mathrm{N}$ & Ammundi \\
\hline 13 & PNR13 & $79^{\circ} 15^{\prime} 21.024^{\prime \prime} \mathrm{E}$ & $12^{\circ} 56^{\prime} 51.612^{\prime \prime} \mathrm{N}$ & Thengal \\
\hline 14 & PNR14 & $79^{\circ} 16^{\prime} 19.488^{\prime \prime} \mathrm{E}$ & $12^{\circ} 55^{\prime} 44.472^{\prime \prime} \mathrm{N}$ & Melvisharam \\
\hline 15 & PNR15 & $79^{\circ} 17^{\prime} 13.812^{\prime \prime} \mathrm{E}$ & $12^{\circ} 55^{\prime} 17.4^{\prime \prime} \mathrm{N}$ & Navlock \\
\hline 16 & PNR16 & $79^{\circ} 18^{\prime} 14.4^{\prime \prime} \mathrm{E}$ & $12^{\circ} 55^{\prime} 4.26^{\prime \prime} \mathrm{N}$ & Veppur \\
\hline 17 & PNR17 & $79^{\circ} 19^{\prime} 50.304^{\prime \prime} \mathrm{E}$ & $12^{\circ} 54^{\prime} 51.516^{\prime \prime} \mathrm{N}$ & Arcot bridge \\
\hline 18 & PNR18 & $79^{\circ} 20^{\prime} 0.24^{\prime \prime} \mathrm{E}$ & $12^{\circ} 54^{\prime} 46.404^{\prime \prime} \mathrm{N}$ & KaspaArcot \\
\hline 19 & PNR19 & $79^{\circ} 20^{\prime} 19.644^{\prime \prime} \mathrm{E}$ & $12^{\circ} 54^{\prime} 29.52^{\prime \prime} \mathrm{N}$ & Muppathuvettiarcot \\
\hline 20 & PNR20 & $79^{\circ} 20^{\prime} 52.08^{\prime \prime} \mathrm{E}$ & $12^{\circ} 54^{\prime} 4.716^{\prime \prime} \mathrm{N}$ & Vannivedu \\
\hline 21 & PNR21 & $79^{\circ} 21^{\prime} 6.156^{\prime \prime} \mathrm{E}$ & $12^{\circ} 53^{\prime} 54.024^{\prime \prime} \mathrm{N}$ & Gudimallur \\
\hline 22 & PNR22 & $79^{\circ} 21^{\prime} 23.616^{\prime \prime} \mathrm{E}$ & $12^{\circ} 53^{\prime} 36.708^{\prime \prime} \mathrm{N}$ & Pachaimman temple \\
\hline 23 & PNR23 & $79^{\circ} 21^{\prime} 52.488^{\prime \prime} \mathrm{E}$ & $12^{\circ} 52^{\prime} 54.12^{\prime \prime} \mathrm{N}$ & Pudupadi \\
\hline 24 & PNR24 & $79^{\circ} 22^{\prime} 39.18^{\prime \prime} \mathrm{E}$ & $12^{\circ} 52^{\prime} 45.984^{\prime \prime} \mathrm{N}$ & Chennasamudram \\
\hline 25 & PNR25 & $79^{\circ} 23^{\prime} 22.38^{\prime \prime} \mathrm{E}$ & $12^{\circ} 52^{\prime} 28.164^{\prime \prime} \mathrm{N}$ & Thirumalaicherry \\
\hline
\end{tabular}

Table 1. Geographical information of Sampling locations in Ponnai River, Tamilnadu.

river meets Palar river. It is the second largest rock type present in the area. They are massive and less weathered than the gneisses. As well as the river cross another hard rock terrain which includes Granite that's present next to Charnockite rock. Small patches of pyroxene granulite occurred at the end of the sample location with the district border of Vellore. Geologically, the basin is underlain by rocks of Archean age consisting of granites, granite gneisses, recent alluvium and soils ${ }^{38}$. Sedimentary deposits are seen along the flood plain of the river that is laid on by the various hard rock formations ${ }^{39,40}$.

\section{Materials}

Sample collection. Sampling sites were selected to cover the entire stream from its source to its confluence with natural and anthropogenic activities ${ }^{41}$. The geographical information of each location (longitude and latitude) is noted and then stored on the internal memory of the Garmin GPS and given Table 1. The samples were collected at 25 different locations PNR1-PNR25 along the Ponnai River (Fig. 1) Tamil Nadu using a stainless steel auger which was cleaned between samples and the first subsample at each point was discarded to avoid cross contamination. In each location, five representative sub-samples, one from the center point and four from the four quadrants of the $1 \mathrm{~m}^{2}$ area of each point, were taken at depth $5 \mathrm{~cm}$ from surface of the riverbed and combined to make one composite sample representing each point on the grid. Sand samples were dried at room temperature $\left(33^{\circ} \mathrm{C}\right)$ and stored in clean polythene bags for further studies ${ }^{42}$.

Sample preparation. For FT-IR study. A fine homogenized powder sample of $2 \mathrm{mg}$ was mixed with $40 \mathrm{mg}$ of $\mathrm{KBr}$ in the ratio 1:20 and it's was ground well using mortar and pestle. Before blending, required amount of $\mathrm{KBr}$ powder was dried at $120^{\circ} \mathrm{C}$ for $6 \mathrm{~h}$ in an oven. If not, the broad spectral peak will appear due to unbound $\mathrm{OH}$ will consequentially affect the interpretation on the bound hydroxyls associated, with any of the minerals ${ }^{1}$. Materials required for $\mathrm{KBr}$ pressed-pellet method are Potassium Bromide (KBr), Acetone; die for making $\mathrm{KBr}$ pellets, laboratory hydraulic press for creating pressure on the confined sample, small hand agate mortar and pestle and mechanical vacuum pump. The prepared pellet was stored in a moisture free glass container before it was placed in a suitable sample holder and it was used for infrared beam for analysis.

For XRD study. The collected sand samples were made into fine-grained particles using agate mortar. Powdered samples are dried and sieved through $2 \mathrm{~mm}$ sieve. Sieved sample is homogenized in a tumbler mixer for $30 \mathrm{~min}$. The prepared samples are then subjected to analysis. 
(OC-Organiccarban, C-Calcite, K-Kaolinite, A-Albite, Q-Quartz, MC-Microcline)

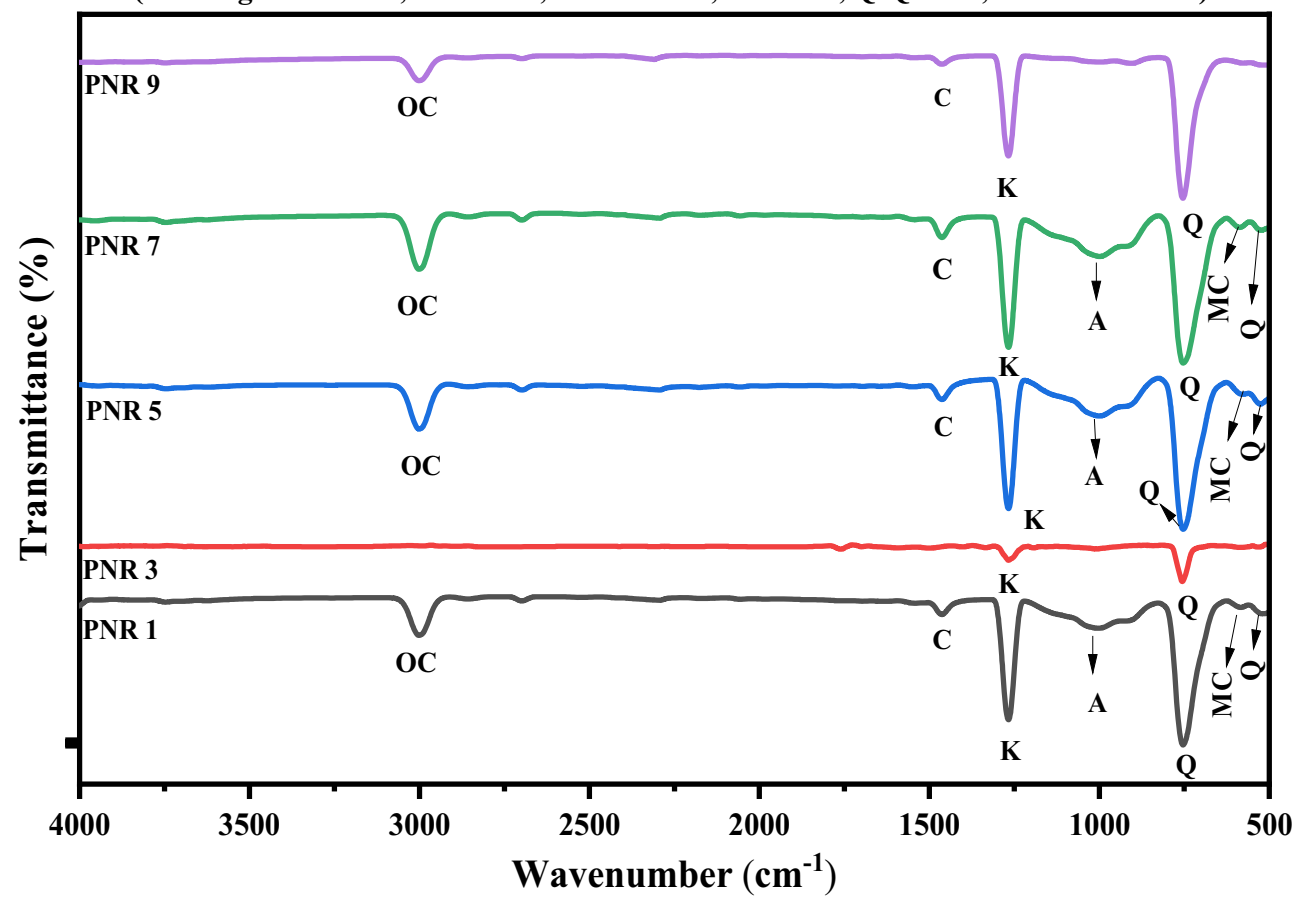

Figure 2. FT-IR spectrum of river sand samples PNR1-PNR9.

For atomic absorption spectrometry (AAS) study. Wet digestion method was used for digestion of the river sand samples. $2.5 \mathrm{~g}$ of each of the air-dried, ground, and sieved samples was accurately weighted into a digestion tube. $10 \mathrm{ml} \mathrm{HNO}_{3}$ and $1 \mathrm{ml} \mathrm{H}_{2} \mathrm{O}_{2}$ were measured and added into the digestive tube and swirled gently to mix the sample properly. The digestion tubes were then placed on digestive furnace and heated at a temperature of $180^{\circ} \mathrm{C}$ for $3 \mathrm{~h}$. All the digests were cooled and filtered through Whatman No.42 filter paper and diluted to $50 \mathrm{ml}$ by double distilled water ${ }^{43}$. Each sample was digested in replicates of five and transferred to acid-washed stoppered glass bottle, labeled and kept for metal analysis.

\section{Methods}

FT-IR analysis. The Fourier transform infrared (FT-IR) spectroscopy is a powerful and well known method implemented to identify the mineral constituents present in the river sand samples. The compounds synthesized were characterized by FT-IR spectra in the region $4000-400 \mathrm{~cm}^{-1}$ using Perkin Elmer FT-IR spectrometer (model: Spectrum 2000). KBr was used to make a pellet format. It also has great importance in resolving the order-disorder for identifying the different functional groups in the mid-infrared area and for structural analysis present in the samples ${ }^{44}$. The recorded FT-IR spectrums for sand samples are given in Fig. 2 (PNR1-PNR9) and Fig. 3 (PNR11-PNR21).

XRD analysis. In the present study, X-ray diffraction patterns were recorded for river sand samples and given in Fig. 4. The obtained XRD patterns were compared data provided by international center diffraction data (ICDD) formerly known as joint committee on powder diffraction standards (JCPDS) for mineral identification ${ }^{45,46}$. In this analysis, only those peaks of the minerals, which did not overlap with sufficient intensity, were considered for identification.

AAS analysis. In the present work, concentrations of heavy metals were determined using a Flame atomic absorption spectrometer (AAS, Analyst iCE3000, Thermo scientific, USA). Qualitative and quantitative of heavy metals are measured based on the measurement of absorption of optical radiation by atoms in the gaseous state $^{27}$. The standard solutions for all the heavy metals under study were prepared in three to five different concentrations to obtain a calibration curve by diluting stock standard solution of concentration 1000 ppm. Regular operating conditions for sample analysis are given in Table 2 . The hollow cathode lamps for $\mathrm{Pb}, \mathrm{As}, \mathrm{Hg}, \mathrm{Cu}, \mathrm{Zn}$, $\mathrm{Cr}, \mathrm{Ni}$ and $\mathrm{Mn}$ were used as radiation source and fuel was air acetylene. All the samples and standard were analyzed in multiple times and average value taken as a results.

SEM-EDS analysis. The determination of concentration of heavy metals present in the samples was done using the Carl Zeiss Microscopy GmbH Germany (EVO 18) Energy Dispersive Xray spectrometer (SEM-EDS). This technique is being used in numerous applications for environmental science and technology. Energy dispersive X-ray spectrometry is a popular method for the determination of trace elements in geological and environ- 
(K-Kaolinite, OC-Organic carbon, C-Calcite, G-Gibbsite, Q-Quartz)

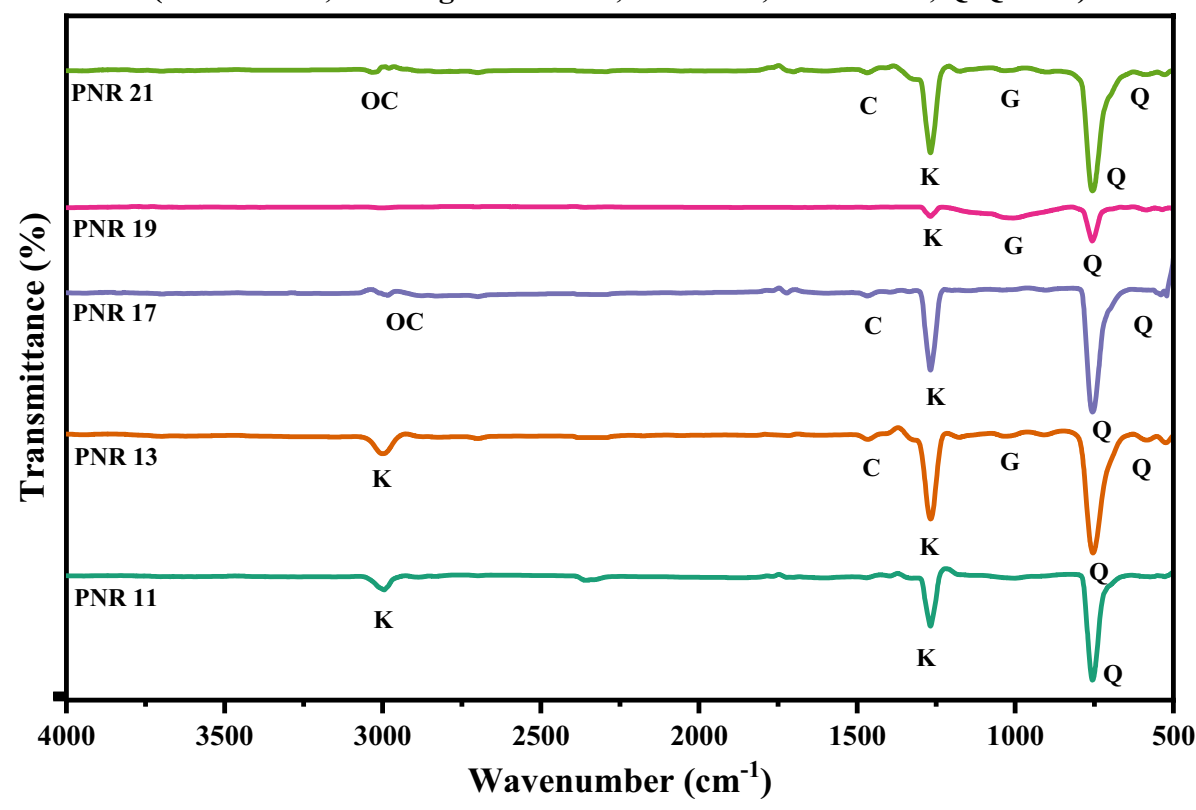

Figure 3. FT-IR spectrum of river sand samples PNR11-PNR21.

(Q - Quartz; K - Kyanite; G - Geothite; M - Microcline; O - Orthoclase)

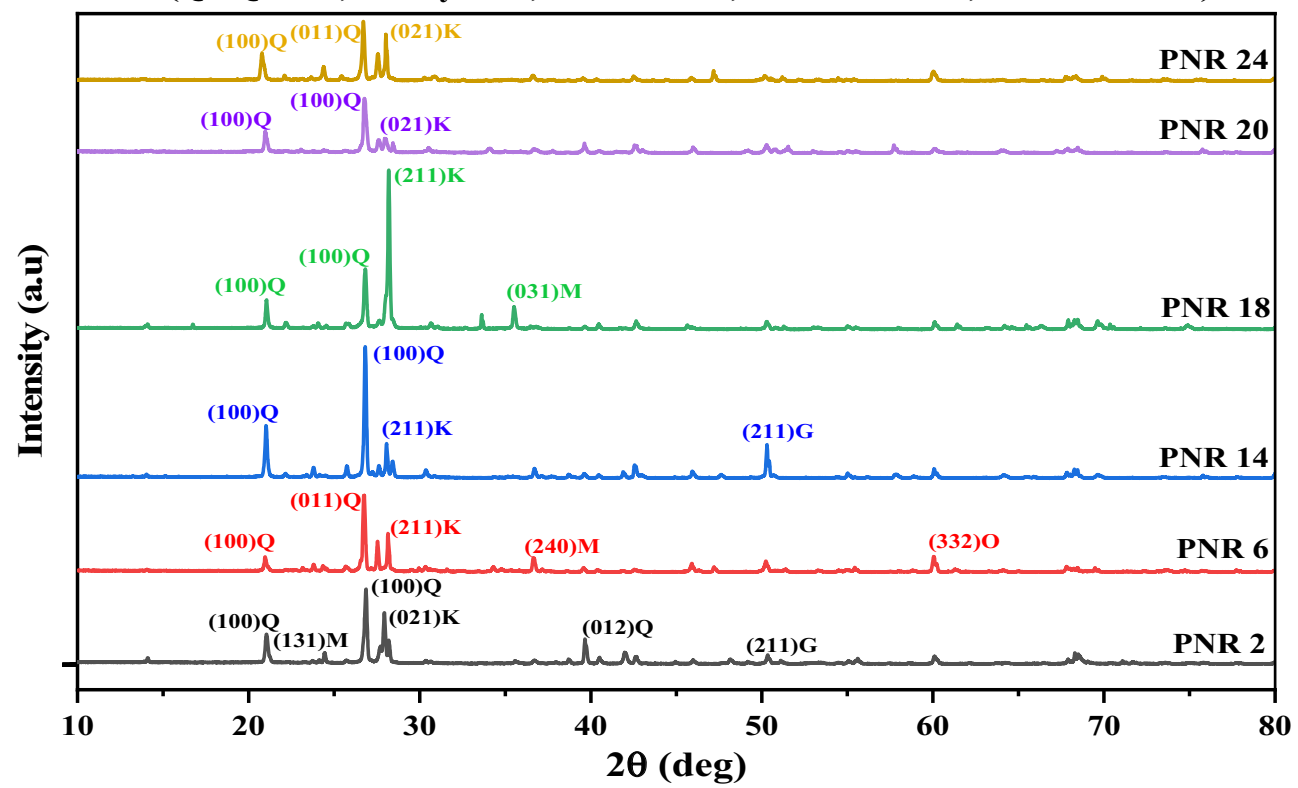

Figure 4. XRD spectrum of river sand samples PNR1-PNR25.

mental samples. With the morphological characters obtained from SEM, supported by Energy dispersive Xray (EDS) micro analysis device, it is possible to identify elements like $\mathrm{Na}, \mathrm{Mg}, \mathrm{Al}, \mathrm{Si}, \mathrm{Cl}, \mathrm{K}, \mathrm{Ca}, \mathrm{Mn}, \mathrm{Fe}, \mathrm{Cr}, \mathrm{Co}, \mathrm{Ni}$, $\mathrm{Cu}, \mathrm{Zn}, \mathrm{As}, \mathrm{Se}, \mathrm{Pb}$ and $\mathrm{Cd}$ in soil and plants.

Multivariate statistical methods. Multivariate statistical techniques could be used to identify similar origins or geochemical characteristics between the heavy metals from their inter-relationship. Hence it is performed to identify the origin of heavy metals for river sand samples using SPSS 16.0. Pearson correlation analysis was carried out to find out the relation between heavy metals. Principal component analysis (PCA) was extracted to identify the natural and anthropogenic origins to be distinguished for metals in the samples. Varimax rotation was applied to highlight the contribution of the most important variables. Then, cluster analysis (CA) was applied using average linkage method and the Euclidean distance as a measure of similarity ${ }^{47}$. Both techniques 


\begin{tabular}{|l|l|l|l|l|l|l|}
\hline S. no. & Heavy metal & Wavelength $(\mathbf{n m})$ & Slit width $(\mathbf{n m})$ & Lamp current $(\mathbf{m A})$ & Instrument mode & Flame type \\
\hline 1 & Arsenic $(\mathrm{As})$ & 193.7 & 0.2 & 5 & Vapour & Argon \\
\hline 2 & Lead $(\mathrm{Pb})$ & 217 & 0.7 & 6 & Flame & Air-acetylene \\
\hline 3 & Chromium $(\mathrm{Cr})$ & 357.9 & 0.4 & 7 & Flame & $\begin{array}{l}\text { Nitrous oxide + Acety- } \\
\text { lene }\end{array}$ \\
\hline 4 & Manganese $(\mathrm{Mn})$ & 279.5 & 0.2 & 5 & Flame & Air-acetylene \\
\hline 5 & Nicel $(\mathrm{Ni})$ & 232 & 0.7 & 7 & Flame & Air-acetylene \\
\hline 6 & Zinc $(\mathrm{Zn})$ & 213.9 & 0.7 & 5 & Flame & Air-acetylene \\
\hline 7 & Mercury $(\mathrm{Hg})$ & 253.7 & 0.7 & 6 & Vapour & Argon \\
\hline 8 & Copper $(\mathrm{Cu})$ & 324.8 & 0.4 & 5 & Flame & Air-acetylene \\
\hline
\end{tabular}

Table 2. FAAS operating conditions for the determination of heavy metals in sand samples.

\begin{tabular}{|c|c|c|c|c|c|c|c|c|c|}
\hline \multirow[b]{2}{*}{ S no. } & \multirow[b]{2}{*}{ Sample ID } & \multirow{2}{*}{\begin{tabular}{|l|}
$\begin{array}{l}\text { Silicate } \\
\text { minerals }\end{array}$ \\
Quartz \\
\end{tabular}} & \multicolumn{2}{|l|}{ Feldspar } & \multirow{2}{*}{$\begin{array}{l}\text { Clay mineral } \\
\text { Kaolinite }\end{array}$} & \multirow{2}{*}{$\begin{array}{l}\text { Organic } \\
\text { carbon }\end{array}$} & \multirow{2}{*}{$\begin{array}{l}\text { Carbonate } \\
\text { minerals } \\
\text { calcite }\end{array}$} & \multirow[b]{2}{*}{ Gibbsite } & \multirow[b]{2}{*}{ References } \\
\hline & & & Microcline & Albite & & & & & \\
\hline 1 & PNR1 & 515,696 & 585 & 785,990 & 1260,3002 & 2955 & 1442,2876 & 1003 & \\
\hline 2 & PNR2 & 513,698 & 589 & 790,990 & 1260,3000 & 2958 & - & 1005 & \\
\hline 3 & PNR3 & 514,698 & 586 & 786,990 & 1260,3690 & 2956 & 1440,2875 & 1005 & \\
\hline 4 & PNR4 & 520,696 & 588 & 787,995 & 1260,3002 & 2955 & 1441,2876 & 1000 & \\
\hline 5 & PNR5 & 520,695 & 585 & 787,995 & 1260,3002 & 2955 & 1440,2878 & 1003 & \\
\hline 6 & PNR6 & 520,696 & 588 & 787,995 & 1260,3002 & 2955 & 1441,2876 & 1000 & \\
\hline 7 & PNR7 & 520,696 & 588 & 787,995 & 1260,3002 & 2955 & 1441,2876 & 1000 & \\
\hline 8 & PNR8 & $525,695,775$ & 587 & 784,996 & $\begin{array}{l}1259,3390 \\
3690\end{array}$ & 2957 & 1445,2878 & 1005 & \\
\hline 9 & PNR9 & 775 & - & 785,990 & 3002 & 2957 & 1445,2878 & 1000 & \\
\hline 10 & PNR10 & 775 & - & 787,995 & 1260,3005 & 2955 & 1441,2877 & 1005 & \\
\hline 11 & PNR11 & 776 & - & - & - & 2956 & 2880 & 1000 & \\
\hline 12 & PNR11 & 775 & - & 787,995 & 1260,3005 & 2955 & 1441,2877 & 1005 & \\
\hline 13 & PNR13 & 775 & - & - & 3002 & - & - & 1005 & $4,49,76-78$ \\
\hline 14 & PNR14 & 513,698 & 589 & 790,990 & 1260,3000 & 2958 & - & 1005 & \\
\hline 15 & PNR15 & $520,695,775$ & 587 & 784,996 & $\begin{array}{l}1259,3390 \\
3690\end{array}$ & 2957 & 1445,2878 & 1005 & \\
\hline 16 & PNR16 & 515,695 & - & 785,995 & 1260,3000 & 2957 & 1445,2875 & 1000 & \\
\hline 17 & PNR17 & 775 & - & - & 1260,3000 & 2956 & 1440,2875 & - & \\
\hline 18 & PNR18 & 775 & - & 787,995 & 1260,3005 & 2955 & 1441,2877 & 1005 & \\
\hline 19 & PNR19 & 513,698 & 589 & 790,990 & 1260,3000 & 2958 & - & 1005 & \\
\hline 20 & PNR20 & 775 & - & 787,995 & 1260,3005 & 2955 & 1441,2877 & 1005 & \\
\hline 21 & PNR21 & 775 & - & 787,995 & 1260,3005 & 2955 & 1441,2877 & 1005 & \\
\hline 22 & PNR22 & 520,696 & 588 & 787,995 & 1260,3002 & 2955 & 1441,2876 & 1000 & \\
\hline 23 & PNR23 & 515,695 & - & 785,995 & 1260,3000 & 2957 & 1445,2875 & 1000 & \\
\hline 23 & PNR24 & 520,696 & 588 & 787,995 & 1260,3002 & 2955 & 1441,2876 & 1000 & \\
\hline 25 & PNR25 & 520,696 & 585 & 787,990 & 1259,3005 & 2958 & 1445,2876 & 1000 & \\
\hline
\end{tabular}

Table 3. Observed absorption frequency in the region $400-4000 \mathrm{~cm}^{-1}$ of sand samples with identified minerals.

were applied to standardized data in order to improve interpretation and avoid misclassification. All of the results were generally consistent with each other.

\section{Results and discussion}

Mineral identification by FT-IR. The observed peak values for the minerals present in the samples are tabulated in Table 3 By using FT-IR absorption peak values; we can identify the major and minor composition in the samples, compared with the already reported literature ${ }^{2,44,48-52}$. The list of various minerals discussion is presented below.

Quartz is the most abundant and widely distributed mineral found at earth's surface. It can be observed from the Table 2, the i.r. absorption bands values appears in the range of 515-520, 695-700, 775-780 $\mathrm{cm}^{-1}$ indicates the availability of quartz in the samples. Microcline $\left(\mathrm{KAlSi}_{3} \mathrm{O}_{8}\right)$ is the triclinic low-temperature K-feldspar stable at temperatures lower than $500{ }^{\circ} \mathrm{C}$. It is usually formed by recrystallization from feldspar, and sometimes 


\begin{tabular}{|l|l|l|l|}
\hline Minerals & Frequency & Tentative assignments & References \\
\hline Quartz & 515 & Si-O asymmetrical bending vibration & 76 \\
\hline Quartz & 695 & Si-O symmetrical bending vibration & 4 \\
\hline Quartz & 775 & Si-O symmetrical stretching vibration & 4 \\
\hline Feldspar & 585 & O-Si(Al)-O bending vibrations & 4 \\
\hline Feldspar & 785 & Si-O symmetrical stretching vibration & 77 \\
\hline Feldspar & 990 & Si-O stretching O-H deformation & 49 \\
\hline Kaolinite & 1255 & Si-O stretching O-H deformation & 49 \\
\hline Kaolinite & 3005 & O-H stretching of inner hydroxyl group & 78 \\
\hline Kaolinite & 3390 & Inner OH stretching vibrations & 4 \\
\hline Kaolinite & 3690 & Inner surface OH stretching vibrations & 4 \\
\hline Calcite & 1445 & Vibrations of C-O bonds in calcite & 1 \\
\hline Gibbsite & 1005 & - & 4 \\
\hline Organic carbon & 2955 & C-H stretching vibration & 78 \\
\hline
\end{tabular}

Table 4. Band assignments of different minerals for river sand samples.

by direct crystallization from magma and hydrothermal processes. For microline the observed peak values are $585-590 \mathrm{~cm}^{-1}$. The absorption peak values are 785-790, 990-995 $\mathrm{cm}^{-1}$ was observed for albite.

Kaolinite is a clay mineral, with chemical formula $\left(\mathrm{Al}_{2} \mathrm{Si}_{2} \mathrm{O}_{5}(\mathrm{OH})_{4}\right)$. From the Table 2, the FT-IR absorption peaks for kaolinite found at 1255-1260, 3000-3005, 3385-3390, 3685-3690 $\mathrm{cm}^{-1}$. Absorbance at $1260 \mathrm{~cm}^{-1}$ is attributed to $\mathrm{Si}-\mathrm{O}$ stretching of clay minerals. From the Table 2, organic carbon peaks are appeared at $2955-2960 \mathrm{~cm}^{-1}$. From this, a very weak absorption band found at 2955 and $2957 \mathrm{~cm}^{-1}$ may suggest the presence of organic carbon ${ }^{53}$. Calcite is a carbonate mineral which is also found in the sand samples. It can be observed from the Table 2, that i.r absorption peaks appear at $1440-1445,2875-2880 \mathrm{~cm}^{-1}$ are assigned to calcite $^{2,53,54}$. Gibbsite is an aluminum hydroxide and secondary mineral which is identified from peak in the range 1000-1005 $\mathrm{cm}^{-1}$. Band assignment for each frequency and minerals are also given in Table 4 .

Mineral confirmation by XRD. Recorded XRD spectrum for samples is given in Fig. 4. Using the XRD parameters, primary and secondary minerals are identified in the river sand samples. Primary mineral such as quartz $\left(\mathrm{SiO}_{2}\right)$, and feldspar $(\mathrm{Na}, \mathrm{K}) \mathrm{AlSi}_{3} \mathrm{O}_{8}$ are identified and chemical composition of these minerals are not altered by naturally since the time of origin. Quartz is the first most abundant mineral in the all studied samples from PNR1-PNR25.

Feldspar group of minerals such as microcline feldspar, orthoclase feldspar and albite are also impartment mineral in the environment samples. In the present study, microcline and orthoclase feldspar minerals are identified in the samples PNR1-PNR5; PNR21-PNR25 and, microcline feldspar and albite are identified in the samples PNR11-PNR15. All these three feldspar group minerals that is microcline feldspar, orthoclase feldspar and albite are identified in the following samples PNR6-10-PNR15; PNR16-PNR20. Hence, the feldspar group of mineral is the second most abundant minerals in the samples.

Kaolinite is a one of the secondary minera ${ }^{55}$. This mineral formation is due to the decomposition and chemical alteration of primary minerals in the samples. It is also well known clay mineral. As seen from the XRD results, kaolinite present at only few samples of PNR1-PNR15 and PNR16-20. Hence it is considered as minor distribution in the samples.

Calcite and aragonite are the carbonate minerals which are major component in the igneous rock. In this work, all the samples (PNR1-PNR25) shows the presence of calcite and aragonite found in the samples of PNR16-PNR25. Hence, the calcite is also considered as major component in the samples.

Zircon is one of heavy mineral distributed as minor constituent in earth crust and found as zirconium silicate mineral with a chemical formula $\mathrm{ZrSiO}_{4}$. It is also one of the primary accessories mineral and found in the samples of PNR1-PNR20. Magnetite is an Iron-oxide mineral with chemical formula $\mathrm{Fe}_{3} \mathrm{O}_{4}$. This mineral is identified in the river sand samples from PNR6 to PNR 25 in the study area.

Kyanite and goethite is common accessory mineral which are found in almost all the river sand samples in the study area. The mineral gibbsite was identified form FT-IR but absent in XRD because this mineral was poor in crystalline nature or not in crystalline structure ${ }^{55}$.

The results obtained from the XRD analysis are good agreement with FT-IR analysis for the minerals quartz, feldspar, kaolinite and calcite. Also these minerals are considered as major component in the river sand samples. Additionally, zircon, aragonite, magnetite and kyanite minerals were identified in the samples using only the XRD method.

Concentration of heavy metals in river sands. The concentration of heavy metals in the river sand samples are reported in Table 5. As seen from Table 5, the concentration of manganese (Mn) was the highest among the heavy metals analyzed from all the sampling locations and the range obtained were found to be $78.05-168.95 \mathrm{mg} \mathrm{kg}^{-1}$ with mean of $104.94 \mathrm{mg} \mathrm{kg}^{-1}$. Chromium $(\mathrm{Cr})$ is very harmful to living organisms. The hexavalent form of $\mathrm{Cr}$ is the most toxic. The minimum level was $5.05 \mathrm{mg} \mathrm{kg}^{-1}$ at PNR13 and the mean value (12.70 $\mathrm{mg} \mathrm{kg}^{-1}$ ) of $\mathrm{Cr}$ was does not exceeded the standard values set by USEPA and toxicity reference value 


\begin{tabular}{|l|l|l|l|l|l|l|l|l|}
\hline \multirow{2}{*}{ Sample ID } & \multicolumn{6}{|l}{ Heavy $\mathbf{m e t a l s}\left(\mathbf{m g ~ k}^{-1}\right)$} \\
\cline { 2 - 9 } & Pb & As & Hg & Cu & Zn & Cr & Ni & Mn \\
\hline PNR1 & 0.13 & 0.14 & 0.11 & 1.68 & 9.31 & 11.26 & 1.87 & 80.26 \\
\hline PNR2 & 0.11 & 0.13 & 0.11 & 1.35 & 8.26 & 9.86 & 1.56 & 78.05 \\
\hline PNR3 & 0.11 & 0.13 & 0.14 & 3.21 & 12.6 & 5.69 & 2.1 & 81.29 \\
\hline PNR4 & 0.13 & 0.11 & 0.13 & 3.65 & 9.1 & 5.26 & 2.69 & 88.96 \\
\hline PNR5 & BLQ & 0.12 & 0.13 & 2.1 & 8.26 & 8.96 & 1.65 & 100.26 \\
\hline PNR6 & 0.12 & 0.14 & 0.11 & 1.8 & 10.26 & 10.63 & 1.89 & 95.89 \\
\hline PNR7 & BLQ & BLQ & BLQ & 1.44 & 10.86 & 5.42 & 1.9 & 89.91 \\
\hline PNR8 & 0.13 & 0.15 & 0.13 & 2.23 & 8.24 & 8.96 & 2.52 & 87.69 \\
\hline PNR9 & 0.11 & 0.16 & 0.14 & 3.21 & 9.65 & 6.89 & 3.65 & 128.02 \\
\hline PNR10 & 0.12 & 0.13 & 0.13 & 3.68 & 8.69 & 10.22 & 2.65 & 110.69 \\
\hline PNR11 & 0.11 & 0.13 & 0.11 & 4.21 & 10.12 & 18.56 & 1.89 & 105.56 \\
\hline PNR12 & 0.11 & 0.15 & 0.11 & 4.63 & 9.87 & 17.16 & 1.47 & 99.26 \\
\hline PNR13 & BLQ & 0.15 & BLQ & 2.21 & 10.26 & 5.05 & 2.43 & 99.56 \\
\hline PNR14 & 0.14 & 0.14 & 0.14 & 3.21 & 8.99 & 6.69 & 3.66 & 100.12 \\
\hline PNR15 & 0.12 & 0.13 & 0.16 & 1.26 & 13.65 & 12.36 & 4.26 & 108.96 \\
\hline PNR16 & 0.11 & 0.16 & 0.13 & 1.68 & 9.63 & 17.89 & 3.98 & 79.36 \\
\hline PNR17 & 0.13 & 0.18 & 0.16 & 3.67 & 8.46 & 10.99 & 3.56 & 84.56 \\
\hline PNR18 & BLQ & 0.16 & BLQ & 3.71 & 14.86 & 19.43 & 4.49 & 100.42 \\
\hline PNR19 & 0.11 & 0.13 & 0.13 & 4.25 & 12.6 & 15.69 & 1.59 & 130.26 \\
\hline PNR20 & 0.13 & 0.14 & 0.16 & 3.98 & 10.26 & 15.89 & 2.87 & 98.65 \\
\hline PNR21 & 0.14 & 0.13 & 0.13 & 1.89 & 11.26 & 16.89 & 3.86 & 152.6 \\
\hline PNR22 & 0.11 & 0.19 & 0.11 & 2.65 & 9.56 & 17.25 & 4.56 & 126.3 \\
\hline PNR23 & BLQ & 0.13 & BLQ & 1.62 & 8.28 & 12.43 & 2.82 & 78.39 \\
\hline PNR24 & 0.12 & 0.18 & 0.14 & 1.67 & 9.87 & 16.55 & 3.01 & 149.65 \\
\hline PNR25 & BLQ & 0.21 & BLQ & 4.99 & 10.76 & 31.47 & 4.69 & 168.95 \\
\hline Average & 0.12 & 0.15 & 0.13 & 2.80 & 10.15 & 12.70 & 2.86 & 104.94 \\
\hline World average Turekian and Wedepohl (1961) $)$ & 20 & 13 & 1.4 & 45 & 95 & 90 & 68 & 850 \\
\hline & & & & & & & & \\
\hline
\end{tabular}

Table 5. Heavy metal concentrations in sand samples collected from Ponnai River, Tamilnadu. BLQ Below limit of quantification.

(TRV). The maximum concentration of $\mathrm{Cr}$ found in the sample at PNR25 was $31.47 \mathrm{mg} \mathrm{kg}^{-1}$ which is slightly higher than the toxicity reference value which is $26 \mathrm{mg} \mathrm{kg}^{-1}$. This high concentration of $\mathrm{Cr}$ can cause lethality to some aquatic species in the river system. This may be due to contamination of samples by effluents from leather industries ${ }^{56}$.

$\mathrm{Cu}$ is an essential metal for all living organisms, but is toxic at high levels. Concentration of copper measured in the sample PNR25 showed a maximum value which is the order of $4.99 \mathrm{mg} \mathrm{kg}^{-1}$. According to United State Environment Protection Agency (USEPA), maximum permissible value for $\mathrm{Cu}$ in the river sand is $31.6 \mathrm{mg} \mathrm{kg}^{-1}$, average shale value (ASV) is $45 \mathrm{mg} \mathrm{kg}^{-1}$ and TRV (toxicity reference value) is $16 \mathrm{mg} \mathrm{kg}^{-1}$. The observed value for $\mathrm{Cu}$ was found below the permissible limit set up by USEPA, ASV and TRV. The concentration of lead $(\mathrm{Pb})$ ranged between 0.11 and $0.14 \mathrm{mg} \mathrm{kg}^{-1}$ with mean value of $0.12 \mathrm{mg} \mathrm{kg}^{-1}$. The obtained value of $\mathrm{Pb}$ in the present study was found below the permissible limit set up by USEPA, ASV, and TRV. Hence, lead (Pb) was the least abundant metal in the river samples and this reveals that few samples are free from automobile exhaust fumes and pesticides. Nickel (Ni) is a highly toxic metal even at low concentration. The concentration of $\mathrm{Ni}$ found in the different samples showed maximum value of $4.69 \mathrm{mg} \mathrm{kg}^{-1}$ at sample PNR25 and mean value is $2.86 \mathrm{mg} \mathrm{kg}^{-1}$. However, the concentration of $\mathrm{Ni}$ was found below the permissible limit at all of the sites.

The average value of $\mathrm{Zinc}(\mathrm{Zn})$ concentration in the sand samples of the River Ponnai was recorded as $10.15 \mathrm{mg} \mathrm{kg}^{-1}$. The observed value of $\mathrm{Zn}$ was found below the permissible limit at all locations proposed by USEPA, ASV, TRV and hence no adverse effect on aquatic biota ${ }^{57}$. Arsenic (As) is a highly toxic element that exists in various species and its average value found to be $0.15 \mathrm{mg} \mathrm{kg}^{-1}$ and Mercury $(\mathrm{Hg})$ is a persistent environmental pollutant with bioaccumulation ability in fish, animals, and human beings and its range between 0.11 and $0.16 \mathrm{mg} \mathrm{kg}^{-1}$ with mean value of $0.13 \mathrm{mg} \mathrm{kg}^{-1}$. The concentration of As and $\mathrm{Hg}$ at all the locations showed that below the permissible limit given by USEPA, ASV, TRV and this reveals that there is absence of As and $\mathrm{Hg}$ contamination found in the study area.

The average concentration of heavy metals of Ponnai river sediments were compared with similar other works in the world and given in Table 6. The mean concentrations of all heavy metals measured in this study were significantly lower than those in the Xiangjiang River, which is one of the most polluted rivers in China ${ }^{58}$. The concentrations of $\mathrm{Pb}$ and $\mathrm{Ni}$ measured in this study were lower than those detected in the Gorges River in Australia $^{59}$ and the Nile River in Egypt, all of which are heavily polluted. 


\begin{tabular}{|c|c|c|c|c|c|c|c|c|c|c|c|}
\hline \multirow[b]{2}{*}{ S. no. } & \multirow[b]{2}{*}{ Country } & \multirow[b]{2}{*}{ River } & \multicolumn{8}{|c|}{ Heavy metal concentration $\left(\mathrm{mg} \mathrm{kg}^{-1}\right)$} & \multirow[b]{2}{*}{ References } \\
\hline & & & As & $\mathbf{P b}$ & $\mathrm{Cu}$ & $\mathrm{Zn}$ & $\mathrm{Hg}$ & Mn & $\mathrm{Ni}$ & $\mathrm{Cr}$ & \\
\hline 1 & China & Xiangjiag river & 54.90 & 214.91 & 101.36 & 443.32 & - & 1805.17 & 57.14 & 120.44 & 58 \\
\hline 2 & Australia & Gorges river & 11.00 & 67.00 & 30.00 & 157.00 & - & - & 13.00 & 39.00 & 59 \\
\hline 3 & Egypt & Nile river & - & 10.36 & 41.64 & 61.70 & - & 774.63 & 48.88 & 72.68 & 60 \\
\hline 4 & Pakistan & Chenab river & - & 18.10 & 8.16 & 33.70 & - & 494.00 & - & - & 70 \\
\hline 5 & Bangladesh & Turag river & - & 32.78 & 50.40 & 139.48 & - & - & - & 43.02 & 71 \\
\hline 6 & Malaysia & Mamut river & - & 23.48 & 583.38 & 61.36 & - & - & 170.74 & - & 72 \\
\hline 7 & France & Gardon of Ales river & 27.96 & 61.23 & - & 182.60 & - & - & - & - & 73 \\
\hline 8 & Spain & Louro river & - & 61.80 & 45.40 & - & - & - & 46.40 & 108.00 & 74 \\
\hline 9 & Singapore & Buloh river & - & 12.28 & 7.06 & 51.24 & - & - & - & 16.61 & 75 \\
\hline 10 & India & Ponnai river & 0.15 & 0.12 & 2.80 & 10.15 & 0.13 & 104.94 & 2.86 & 12.70 & Present study \\
\hline
\end{tabular}

Table 6. Comparison of metal concentration in river sediments with other countries.

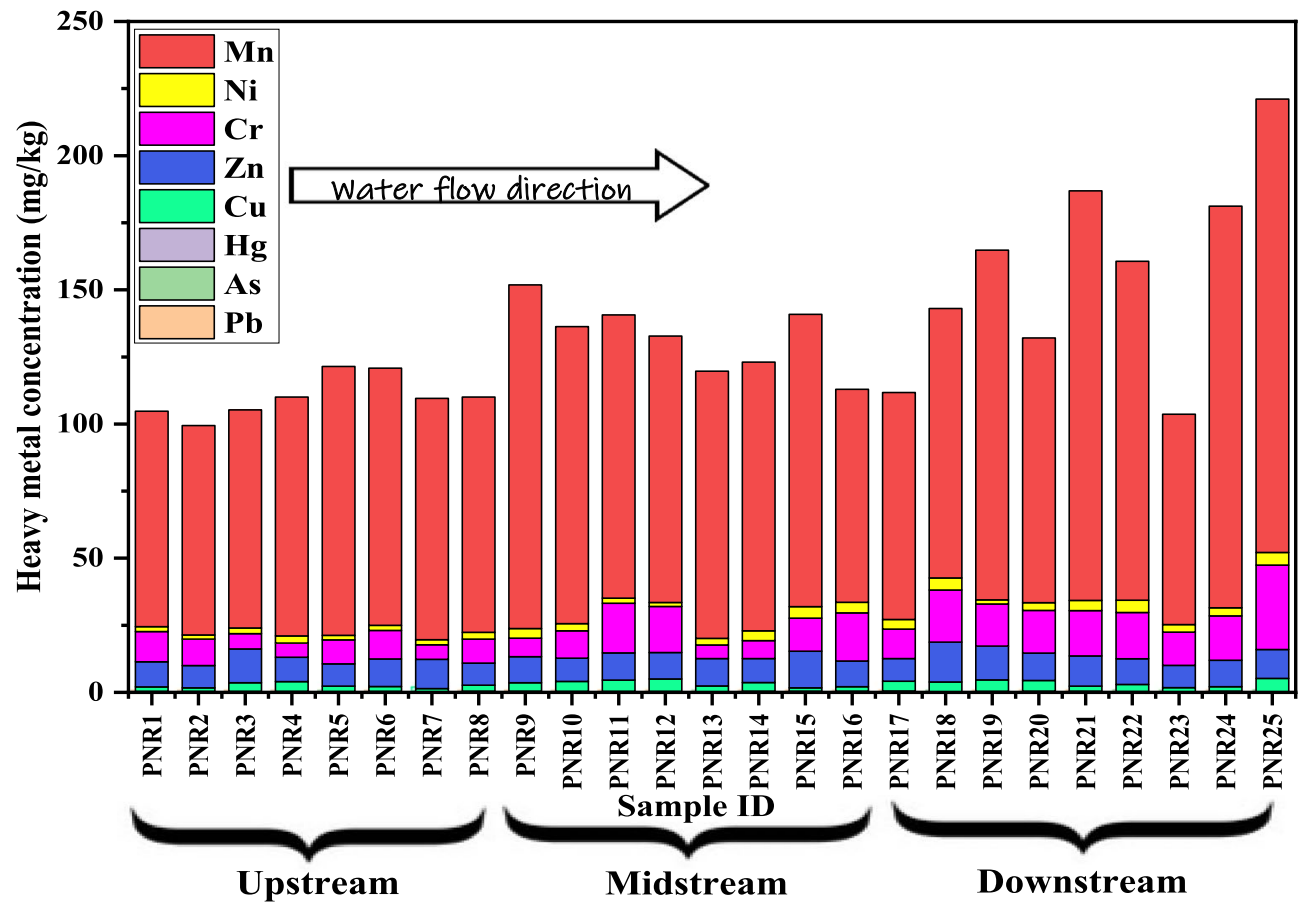

Figure 5. Variation of heavy metal concentration in Ponnai river, Tamilnadu.

Spatial distribution of heavy metals. Spatial distribution of heavy metals was studied from sampling location PNR1 to PNR25 and shown in Fig. 5. It is observed from Fig. 5, Mn has the highest concentration at PNR25 (168.95 mg kg$\left.{ }^{-1}\right)$ and then the next highest at PNR21 $\left(150.2 \mathrm{mg} \mathrm{kg}^{-1}\right)$. This indicates that concentration of $\mathrm{Mn}$ is high at downstream sampling pints (PNR17-PNR25). The total concentration of heavy metals gradually increases as the water flows PNR1 to PNR25. There is no significant difference found in the concentrations of heavy metals within the upstream (PNR1-PNR8) river area and within the midstream (PNR9-PNR16), but there is a significant difference within the downstream (PNR17-PNR25) due to discharge of sewage from households, leather industry, and transport.

Confirmation of presence of heavy metals by SEM-EDS. Studied heavy metals were found in all river sand samples mainly as small particles $(<50 \mu \mathrm{m})$. These particles were frequently identified inside aggregates as shown in Fig. 6a. In the view point of SEM/EDS, heavy metals $(<1 \mathrm{wt} \%)$ are detectable since they are concentrated in a structure ${ }^{60}$. SEM/EDS results confirm the presence of $\mathrm{Zn}, \mathrm{Cr}, \mathrm{Pb}, \mathrm{Ni}, \mathrm{Cu}, \mathrm{Mn}, \mathrm{As}$ and $\mathrm{Hg}$ in the sand samples. In addition $\mathrm{Si}$ and $\mathrm{O}$ were identified in the samples and illustrated in Fig. $6 \mathrm{~b}$.

Statistical analysis of heavy metals. Pearson correlation analysis. Pearson correlation analysis was performed between the heavy metals to evaluate the inter-element relationship of metals and identify the source 


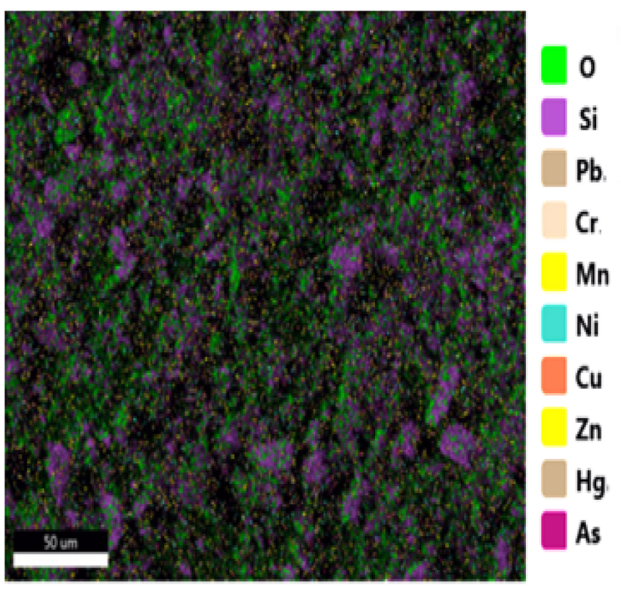

(a)

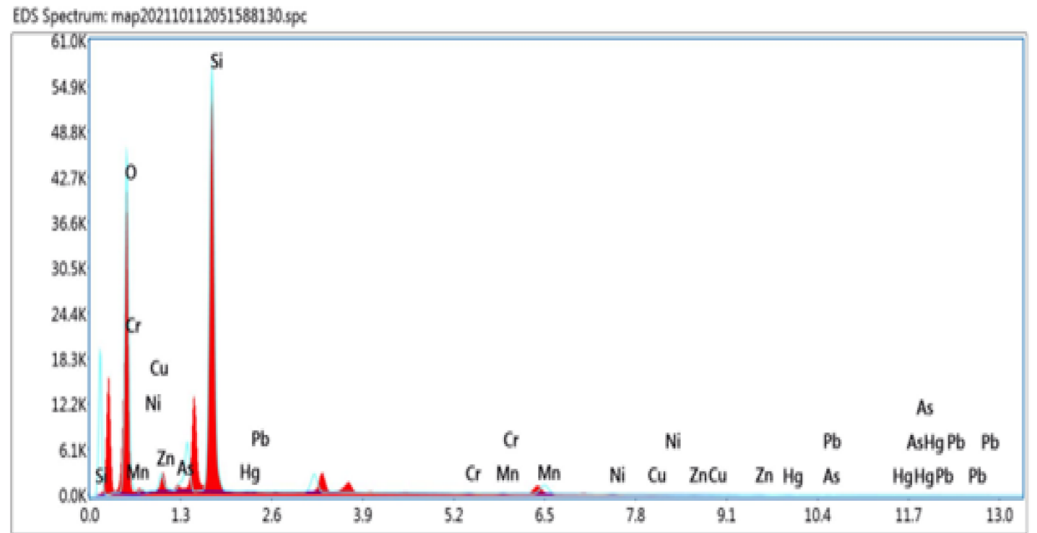

$1036 \mathrm{~K}$ Cints $3.390 \mathrm{keV}$ Det: Element-C2B Lock Mop/line Elements

(b)

Figure 6. Typical SEM-EDS analysis image and spectrum for sand sample PNR25.

\begin{tabular}{|l|l|l|l|l|l|l|l|l|}
\hline \multicolumn{2}{|l|}{ Correlations } \\
\hline Variables & As & Hg & Cu & Zn & Cr & Ni & Mn & Pb \\
\hline $\mathrm{As}$ & 1 & & & & & & & \\
\hline $\mathrm{Hg}$ & 0.153 & 1 & & & & & & \\
\hline $\mathrm{Cu}$ & 0.323 & 0.019 & 1 & & & & & \\
\hline $\mathrm{Zn}$ & -0.055 & $\mathbf{0 . 4 3 8}$ & 0.150 & 1 & & & & \\
\hline $\mathrm{Cr}$ & $\mathbf{0 . 5 4 7}$ & -0.201 & $\mathbf{0 . 4 0 0}$ & 0.271 & 1 & & & \\
\hline $\mathrm{Ni}$ & $\mathbf{0 . 5 1 1}$ & -0.079 & 0.077 & 0.277 & $\mathbf{0 . 4 4 0}$ & 1 & & \\
\hline $\mathrm{Mn}$ & $\mathbf{0 . 4 9 0}$ & -0.031 & 0.287 & 0.258 & $\mathbf{0 . 5 8 3}$ & $\mathbf{0 . 4 3 3}$ & 1 & \\
\hline $\mathrm{Pb}$ & 0.015 & $\mathbf{0 . 4 6 4}$ & -0.065 & -0.207 & -0.189 & 0.156 & 0.008 & 1 \\
\hline
\end{tabular}

Table 7. Pearson correlation analysis among the heavy metals. Significant values are in bold.

and pathways of heavy metals. The obtained results of Pearson correlation analysis for heavy metals were given in Table 6. According to Rakesh and Raju ${ }^{61}$, high correlation coefficient (near +1 or -1 ) means a positive correlation between two variables, and its concentration around zero means no relationship between them at a significant level of $0.05 \%$, it can be strongly correlated, if $r>0.7$, whereas $r$ values between 0.4 and 0.7 shows moderate correlation between two different variables. Pearson correlation analysis was performed between the heavy metals and given Table 7 . The obtained result reveals that there are no strong positive correlations were reordered. But a moderate correlation $(\mathrm{r}>0.438)$ was found between $\mathrm{As}-\mathrm{Cr}-\mathrm{Ni}-\mathrm{Mn}$ and $\mathrm{Hg}-\mathrm{Pb}-\mathrm{Zn}$, indicate that the general contamination sources of these metals were primarily discharge of effluents from domestic and industry ${ }^{62-64}$. A very weak correlation was observed between $\mathrm{Cu}$ and other studied metals at $\mathrm{p}<0.01$. This indicates that $\mathrm{Cu}$ was derived in part from natural source (local soil or rock) ${ }^{63}$. Zn showed poor correlation with all other metals except $\mathrm{Hg}$ (0.438), which may be due to the influence of transport activities near to the river $\operatorname{area}^{65,66}$.

Principal component analysis. Principal component analysis (PCA) identifies the potential sources of heavy metal contamination. As part of this procedure, correlation matrixes are prepared between heavy metal variables, PCs are extracted and possible rotation is performed to reach a final solution with simpler PCs. In principal component analysis, the PC1 tends to be more general, representing the most important common part of the variables analyzed. This PC1 is the best summary of the linear relationship exhibited by the data. The PC2 is independent of the first one (orthogonal), considering only the residual variance not included in the PC1, and so successively for the other axes. In this study it was decided to retain two factors for interpretation, accounting for approximately $36.59 \%$ of the total variance. To obtain more reliable information about the relationships between the heavy metals, principal component analysis was performed using varimax rotation method using Kaiser Normalization and extracted data loadings are given in Table 8. The results of PCA indicated that all the heavy metals are well represented by two components ${ }^{64}$. The principal components with eigenvalues greater than 1 were considered to be relevant ${ }^{32}$, which explains approximately $36.59 \%$ of the total variance for the data. Components with factor loadings above 0.75 , between 0.5 and 0.75 , and between 0.3 and 0.5 were considered to be strong, moderate and weak, respectively ${ }^{33}$. As shown in Table 8, PC1 included As, Cr, Ni, Mn; PC2 included 


\begin{tabular}{|l|r|r|}
\hline Variables & \multicolumn{1}{|c|}{ PC1 } & \multicolumn{1}{l|}{ PC2 } \\
\hline $\mathrm{As}$ & $\mathbf{0 . 4 3 5}$ & 0.126 \\
\hline $\mathrm{Hg}$ & -0.058 & $\mathbf{0 . 4 6 2}$ \\
\hline $\mathrm{Cu}$ & 0.321 & 0.262 \\
\hline $\mathrm{Zn}$ & 0.277 & $\mathbf{0 . 5 3 2}$ \\
\hline $\mathrm{Cr}$ & $\mathbf{0 . 7 3 6}$ & 0.362 \\
\hline $\mathrm{Ni}$ & $\mathbf{0 . 4 5 9}$ & 0.185 \\
\hline $\mathrm{Mn}$ & $\mathbf{0 . 9 9 3}$ & -0.121 \\
\hline $\mathrm{Pb}$ & -0.021 & $\mathbf{0 . 5 1 3}$ \\
\hline \% of variance explained & $\mathbf{2 5 . 3 4}$ & $\mathbf{1 1 . 2 5}$ \\
\hline
\end{tabular}

Table 8. Rotated principal component analysis for heavy metals. Significant values are in bold.

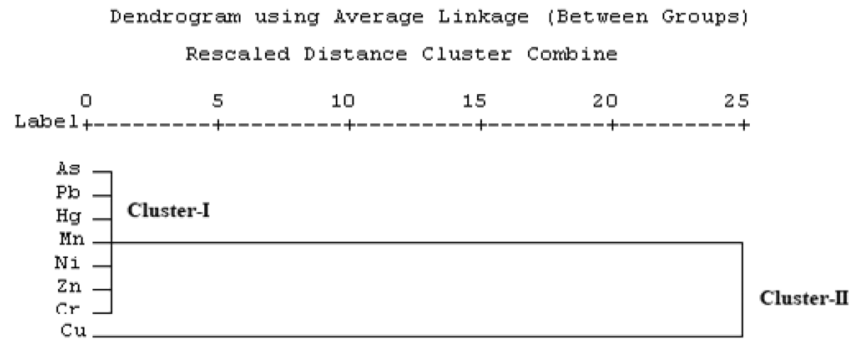

Figure 7. Clustering of heavy metals in river sand samples.

$\mathrm{Hg}, \mathrm{Zn}, \mathrm{Pb}$. This implies that heavy metals $\mathrm{As}, \mathrm{Cr}, \mathrm{Ni}, \mathrm{Mn}$, were derived from anthropogenic activities such as sewage from, domestic, leather industry and transport ${ }^{63,67}$.

Cluster analysis. According to Kannel et al. ${ }^{68}$, the cluster analysis is a multivariate statistical technique and commonly used in several environmental studies to identify groups or clusters of same variables based on similarities. CA, which involves the evaluation of proximity matrix of squared Euclidean distance along with an agglomeration schedule for clustering similar variables. This method is regarded as very efficient and yields clearly structured and relatively stable clusters ${ }^{69}$. In the present work, the cluster analysis was performed using the heavy metal data set and presented in a two-dimensional dendrogram plot as shown in Fig. 7.

This dendrogram contains two clusters. Cluster I consists $\mathrm{As}, \mathrm{Pb}, \mathrm{Hg}, \mathrm{Ni}, \mathrm{Zn}$ and $\mathrm{Cr}$. This first cluster group of metals ( $\mathrm{As}, \mathrm{Pb}, \mathrm{Cr}, \mathrm{Ni}, \mathrm{Hg}$, and $\mathrm{Zn}$ ) shows the high similarities which imply that these heavy metals were mainly derived anthropogenic activities such as industrials and transport activities. Cluster II consist only $\mathrm{Cu}$ which indicate that $\mathrm{Cu}$ is derived from weathering of parent rock in the study area. These results are good agreement with PCA and Pearson correlation analysis.

\section{Conclusion}

Ponnai river sand samples were characterized by different spectroscopic techniques to determine the presence of minerals and heavy metals. From the results of FT-IR, it is concluded that the minerals like quartz, feldspar, gibbsite and calcite are major constituent and kaolinite is the minor constituent in the samples. The presence of these minerals has also confirmed by XRD technique. This XRD treatment of samples shows that presence of accessory minerals such as zircon, aragonite, magnetite and kyanite in the samples. The identified peaks of FT-IR and XRD for minerals indicate that sample quality is not affected by anthropogenic activities. Further, among the determined heavy metals manganese $(\mathrm{Mn})$ was the most abundant and lead $(\mathrm{Pb})$ was the least abundant heavy metal found in study area. The total concentration of heavy metals gradually increases as the water flows from PNR1 to PNR25. The maximum concentration of Cr found in the sample at PNR25 is $31.47 \mathrm{mg} \mathrm{kg}^{-1}$ which is slightly higher than the toxicity reference value which is $26 \mathrm{mg} \mathrm{kg}^{-1}$. This may be due to contamination of samples by effluents from leather industries located near to the study area. Using SEM/EDS, heavy metals $(<1 \mathrm{wt} \%)$ are detected SEM/EDS results confirms the presence of $\mathrm{Zn}, \mathrm{Cr}, \mathrm{Pb}, \mathrm{Ni}, \mathrm{Cu}, \mathrm{Mn}, \mathrm{As}$ and $\mathrm{Hg}$ in the sand samples. The result of multivariate statistical methods reveals that studied metals $\mathrm{As}, \mathrm{Cr}, \mathrm{Ni}, \mathrm{Mn}, \mathrm{Hg}, \mathrm{Pb}$ were deposited in samples due to discharge of effluents from domestic and industry while $\mathrm{Zn}$ was derived from transport activities. In addition to that, $\mathrm{Cu}$ was derived in samples due to weathering of local soil or rocks in the study area. Hence, the results of this study indicate that that quality of the sand samples is altered by both natural and anthropogenic activities daily and needs continuous monitoring to establish the pollution level of the study area. 
Received: 18 June 2021; Accepted: 15 November 2021

Published online: 01 December 2021

\section{References}

1. Ravisankar, R. et al. Mineral analysis in beach rocks of Andaman Island, India by spectroscopic techniques. Arch. Appl. Sci. Res. 3, 77-84. https://doi.org/10.1007/s13201-019-1031-8 (2011).

2. Ramasamy, V., Paramasivam, K., Suresh, G. \& Jose, M. T. Function of minerals in the natural radioactivity level of Vaigai River sediments, Tamilnadu, India: Spectroscopical approach. Spectrochim. Acta A. 117, 340-350. https://doi.org/10.1016/j.saa.2013. $08.022(2014)$.

3. Ramasamy, V., Rajkumar, P. \& Ponnusamy, V. Depth wise analysis of recently excavated Vellar river sediments through FTIR and XRD studies. Indian J. Phys. 83, 1295-1308. https://doi.org/10.1007/s12648-009-0110-3 (2009).

4. Ravisankar, R., Senthilkumar, G., Kiruba, S., Chandrasekaran, A. \& Jebakumar, P. P. Mineral analysis of coastal sediment samples of Tuna, Gujarat, India. Indian J. Sci. Technol. 3, 774-780. https://doi.org/10.17485/ijst/2010/v3i7.14 (2010).

5. Bishop, J. L. et al. Mineralogical analyses of surface sediments in the Antarctic Dry Valleys: Coordinated analyses of Raman spectra, reflectance spectra and elemental abundances. Philos. Trans. R. Soc. 372, 20140198. https://doi.org/10.1098/rsta.2014.0198 (2014).

6. Claridge, G. G. C. The clay mineralogy and chemistry of some soils from the Ross Dependency, Antarctica. N. Z. J. Geol. Geophys. 8, 186-220. https://doi.org/10.1080/00288306.1965.10428107 (1965).

7. Song, Z., Chouparova, E., Jones, K. W., Feng, H. \& Marinkovic, N. S. FTIR investigation of sediments from NY/NJ Harbor, San Diego Bay, and the Venetian Lagoon. NSLS Activity Rep. 2, 112-116 (2001).

8. Huang, Z., Liu, C., Zhao, X., Dong, J. \& Zheng, B. Risk assessment of heavy metals in the surface sediment at the drinking water source of the Xiangjiang River in South China. Environ. Sci. Eur. 32, 1-9. https://doi.org/10.1186/s12302-020-00305-w (2020).

9. Bilos, C., Colomobo, J. C., Skorupka, C. N. \& RodriguezPresa, M. J. Source distribution and variability of airborne trace metals in La Plata city area Argentina. Environ. Pollut. 111, 149-158. https://doi.org/10.1016/S0269-7491(99)00328-0 (2001).

10. Madrid, L., Díaz-Barrientos, E. \& Madrid, F. Distribution of heavy metal contents of urban soils in parks of Seville. Chemosphere 49, 1301-1308. https://doi.org/10.1016/S0045-6535(02)00530-1 (2002).

11. Han, Y., Du, P., Cao, J. \& Posmentier, E. S. Multivariate analysis of heavy metal contamination in urban dusts of Xian, Central China. Sci. Total Environ. 355, 176-186. https://doi.org/10.1016/j.scitotenv.2005.02.026 (2006).

12. Dimitrovska, O., Markoski, B., Toshevska, B. P., Milevski, I. \& Gorin, S. Surface water pollution of major rivers in the Republic of Macedonia. Procedia. Environ. Sci. 14, 32-40. https://doi.org/10.1016/j.proenv.2012.03.004 (2012).

13. Venkatramanan, S., Chung, S. Y., Lee, S. Y. \& Park, N. Assessment of river water quality via environmentric multivariate statistical tools and water quality index: A case study of Nakdong river basin. Carpathian J. Earth Environ. Sci. 9, 125-132 (2014).

14. Akcay, H., Oguz, A. \& Karapire, C. Study of heavy metal pollution and speciation in Buyak Menderes and Gediz river sediments. Water Res. 37, 813-822. https://doi.org/10.1016/S0043-1354(02)00392-5 (2003).

15. Olivares-Rieumont, S. et al. Assessment of heavy metal levels in Almendares River sediments-Havana City, Cuba. Water Res. 39, 3945-3953. https://doi.org/10.1016/j.watres.2005.07.011 (2005).

16. Wang, Y. et al. Assessment of heavy metals in sediments from a typical catchment of the Yangtze River, China. Environ. Monit. Assess. 172, 407-417. https://doi.org/10.1007/s10661-010-1343-5 (2011).

17. Li, X. et al. Distribution and speciation of heavy metals in surface sediments from the Yangtze estuary and coastal areas. Environ. Earth Sci. 69, 1537-1547. https://doi.org/10.1007/s12665-012-1988-1 (2013).

18. Pejman, A., Bidhendi, G. N., Ardestani, M., Saeedi, M. \& Baghvand, A. A new index for assessing heavy metals contamination in sediments: A case study. Ecol. Ind. 58, 365-373. https://doi.org/10.1016/j.ecolind.2015.06.012 (2015).

19. Huang, Z., Zhao, W., Xu, T., Zheng, B. \& Yin, D. Occurrence and distribution of antibiotic resistance genes in the water and sediments of Qingcaosha Reservoir, Shanghai, China. Environ. Sci. Eur. 31, 1-9. https://doi.org/10.1186/s12302-019-0265-2 (2019).

20. Shyleshchandran, M. N., Mohan, M. \& Ramasamy, E. V. Risk assessment of heavy metals in Vembanad Lake sediments (south-west coast of India), based on acid-volatile sulfide (AVS)-simultaneously extracted metal (SEM) approach. Environ. Sci. Pollut. Res. 25, 7333-7345. https://doi.org/10.1007/s11356-017-0997-8 (2018).

21. Liu, M. et al. Fraction distribution and leaching behavior of heavy metals in dredged sediment disposal sites around Meiliang Bay, Lake Taihu (China). Environ. Sci. Pollut. Res. 25, 9737-9744. https://doi.org/10.1007/s11356-018-1249-2 (2018).

22. Ernst, T., Popp, R. \& Eldik, R. Quantification of heavy metals for the recycling of waste plastics from the electro technical applications. Talanta 53, 347-357. https://doi.org/10.1016/S0039-9140(00)00491-4 (2000).

23. Ritter, A., Michel, R., Schmid, M. \& Affolter, S. Inter laboratory test on polymers: determination of heavy metals in polymer metrices. Polym. Test. 23, 467-474. https://doi.org/10.1016/j.polymertesting.2003.09.001 (2004).

24. US Environmental Protection Agency. EPA Method 3060A. Alkaline Digestion for Hexavalent Chromium, 1-15 (US EPA Office of Solid Waste, 1996).

25. US Environmental Protection Agency. EPA Method 7196A. Chromium, Hexavalent (Colorimetric). 1-6 (US EPA Office of Solid Waste, 1992).

26. Wolska, J. Elemental analysis in the plastic industry. Plast. Addit. Compd. 5, 50-55. https://doi.org/10.1016/S1464-391X(03)80111-3 (2003).

27. Asare, E. A., Zaini, B. A., Rafeah, B. W., Droepenu, E. K. \& Wilson, F. Veochemical exploration of sediment samples from the Sebangan River. Adv. Anal. Chem. 9, 23-33. https://doi.org/10.5923/j.aac.20190902.01 (2019).

28. Hani, A. \& Pazira, E. Heavy metals assessment and identification of their sources in agricultural soils of Southern Tehran, Iran. Environ. Monit. Assess. 176, 677-691. https://doi.org/10.1007/s10661-010-1612-3 (2011).

29. Huang, W., Campredon, R., Abrao, J. J., Bernat, M. \& Latouche, C. Variation of heavy metals in recent sediments from Piratininga Lagoon (Brazil): Interpretation of geochemical data with the aid of multivariate analysis. Environ. Geol. 23, 241-247. https://doi. org/10.1007/BF00766738 (1994).

30. Dragovic, S. \& Mihailovic, N. Analysis of mosses and top soils for detecting sources of heavy metal pollution: Multivariate and enrichment factor analysis. Environ. Monit. Assess. 157, 383-390. https://doi.org/10.1007/s10661-008-0543-8 (2009).

31. Qiao, M. et al. Characterization of soil heavy metal contamination and potential health risk in metropolitan region of northern China. Environ. Monit. Assess. 172, 353-365. https://doi.org/10.1007/s10661-010-1339-1 (2011).

32. Hu, K. L., Zhang, F. R., Lu, Y. Z., Wang, R. \& Xu, Y. Spatial distribution of concentrations of soil heavy metals in Daxing county, Beijing. Acta Sci. Circum. 24, 463-469 (2011).

33. Ruiz, F. et al. Stratigraphic sequence, elemental concentrations and heavy metal pollution in Holocene sediments from the TintoOdiel Estuary, southwestern Spain. Environ. Geol. 34, 270-278. https://doi.org/10.1007/s002540050278 (1998).

34. Yang, P., Mao, R., Shao, H. \& Gao, Y. The spatial variability of heavy metal distribution in the suburban farmland of Taihang Piedmont Plain, China. C. R. Biol. 332, 558-566. https://doi.org/10.1016/j.crvi.2009.01.004 (2009).

35. Franco-Uria, A., Lopez-Mateo, C., Roca, E. \& Fernandez-Marcos, M. L. Source identification of heavy metals in pastureland by multivariate analysis in NW Spain. J. Hazard. Mater. 165, 1008-1015. https://doi.org/10.1016/j.jhazmat.2008.10.118 (2009).

36. Yao, R. J. et al. Multivariate simulation and assessment of three dimensional spatial patterns of coastal soil salinity using ancillary variables. Fresenius Environ. Bull. 22, 39-52 (2013).

37. Isaaks, E. H. \& Srivastava, R. M. An Introduction to Applied Geostatistics (Oxford University Press, 1989). 
38. Rao, S. Y., Reddy, T. V. K. \& Nayudu, P. T. Groundwater targeting in a hard-rock terrain using fracture-pattern modelling, Niva River basin, Andhra Pradesh, India. Hydrogeol. J. 8, 494-502. https://doi.org/10.1007/s100400000090 (2000).

39. CGWB. District Groundwater Brochure Vellore District, Tamil Nadu. (Central Ground Water Board, Minerial of Water Resources, Govt of India, 2009).

40. Sajil Kumar, P. J., Jegathambal, P. \& James, E. J. Factors influencing the high fluoride concentration in groundwater of Vellore District, South India. Environ. Earth Sci. 7, 2437-2446. https://doi.org/10.1007/s12665-014-3152-6 (2014).

41. Gabrielyan, A. V., Shahnazaryan, G. A. \& Minasyan, S. H. Distribution and identification of sources of heavy metals in the Voghji River basin impacted by mining activities (Armenia). J. Chem. https://doi.org/10.1155/2018/7172426 (2018).

42. Golden, N., Morrison, L., Gibson, P. J., Potito, A. P. \& Zhang, C. Spatial patterns of metal contamination and magnetic susceptibility of soils at an urban bonfire site. J. Appl. Geochem. 52, 86-96. https://doi.org/10.1016/j.apgeochem.2014.11.004 (2015).

43. Hashim, R., Song, T. H., Muslim, N. Z. M. \& Yen, T. P. Determination of heavy metal levels in fishes from the lower reach of the Kelantan River Kelantan Malaysia. Trop. Life Sci. Res. 25, 21-39 (2014).

44. Benedetto, G. E. D., Laviano, R., Sabbatini, L. \& Zambonin, P. G. Infrared spectroscopy in the mineralogical characterization of ancient pottery. J. Cult. Herit. 3, 177-186. https://doi.org/10.1016/S1296-2074(02)01178-0 (2002).

45. Berry, I. G. Selected powder diffraction data for mineralogy, 1-23, (Joint Committee on Powder Diffraction Standards (JCPDS), 1974).

46. Ramasamy, V., Suresh, G., Meenakshisundaram, V. \& Ponnusamy, V. Horizontal and vertical characterization of radionuclides and 225 minerals in river sediments. Appl. Radiat. Isot. 69, 184-195. https://doi.org/10.1016/j.apradiso.2010.07.020 (2011).

47. Silva, Y. J. A. B., Cantalice, J. R. B., Singh, V. P., Nascimento, C. W. A. \& Wilcox, B. P. Heavy metal concentrations and ecological risk assessment of the suspended sands of a multi-contaminated Brazilian watershed. Acta Sci. Agron. 1, 2-11. https://doi.org/10. 4025/actasciagron.v41i1.42620 (2019).

48. Ghosh, S. N. Infrared spectra of some selected minerals, rocks and products. J. Mater. Sci. 13, 1877-1886. https://doi.org/10.1007/ BF00552894 (1978).

49. Russell, J. D. Infrared methods. In A Handbook of Determinative Methods in Clay Mineralogy (ed. Wilson, M. J.) 11-67 (Blackie and Son Ltd, 1987).

50. Sivakumar, S., Ravisankar, R., Raghu, Y., Chandrasekaran, A. \& Chandramohan, A. FTIR spectroscopic studies on coastal sediment samples from Cuddalore district, Tamilnadu, India. Indian J. Adv. Chem. Sci. 1, 40-46 (2012).

51. Ravisankar, R. et al. Analytical characterization of recently excavated megalithic sarcophagi potsherds in Veeranam village Tiruvannamalai dist., Tamilnadu, India. Spectrochim. Acta A. 115, 845-853. https://doi.org/10.1016/j.saa.2013.06.123 (2013).

52. Chandrasekaran, A., Rajalakshmi, A., Ravisankar, R. \& Kalarasai, S. Analysis of beach rock samples of Andaman Island, India by spectroscopic techniques. Egypt. J. Basic Appl. Sci. 2, 55-64. https://doi.org/10.1016/j.ejbas.2014.12.004 (2015).

53. Ravisankar, R., Eswaran, P., Rajalakshmi, A., Chandrasekaran, A. \& Dhinakaran, B. Beach rocks from the south east coast of Tamilnadu, India: A spectroscopic study. Adv. Appl. Sci. Res. 3, 95 (2012).

54. Ravisankar, R. Application of Spectroscopic techniques for the identification of minerals from beach rocks of Tamilnadu, India. Explor. Res. At. Miner. 19, 272-276 (2009).

55. Pei, Y. \& Pei, Y. C. Table of Key Lines in X-ray Powder Diffraction Patterns of Minerals in Clays and Associated Rocks. (Department of natural resources, geological survey occasional paper, 1977).

56. USEPA. National Recommended Water Quality Criteria-Correction-United State Environmental Protection Agency. http://www.epa. gov/ostwater/pci/revcom, 822-Z-99-001, 25. (1999).

57. Singh, H., Singh, D., Singh, S. K. \& Shukla, D. N. Assessment of river water quality and ecological diversity through multivariate statistical techniques, and earth observation dataset of rivers Ghaghara and Gandak, India. Int. J. River Basin Manag. 15, 347-360. https://doi.org/10.1080/15715124.2017.1300159 (2017).

58. Chai, L. et al. Heavy metals and metalloids in the surface sediments of the Xiangiiang River, Hunan, China: Distribution, contamination, and ecological risk assessment. Environ. Sci. Pollut. Res. 24, 874-885. https://doi.org/10.1007/s11356-016-7872-x (2017).

59. Alyazichi, Y. M., Jones, B. G., McLean, E., Pease, J. \& Brown, H. Geochemical assessment of trace element pollution in surface sediments from the Georges River, Southern Sydney, Australia. Arch. Environ. Contam. Toxicol. 72, 247-259. https://doi.org/10. 1007/s00244-016-0343-z (2017).

60. Goldstein, J. et al. Scanning Electron Microscopy and X-Ray Microanalysis (Springer, 2003).

61. Sharma, M. R. \& Raju, N. S. Correlation of heavy metal contamination with soil properties of industrial areas of Mysore, Karnataka, India by cluster analysis. Int. J. Environ. Sci. 2, 22-27 (2013).

62. de Miguel, E. et al. Origin and patterns of distribution of trace elements in street dust: Unleaded petrol and urban lead. Atmos. Environ. 31, 2733-2740. https://doi.org/10.1016/S1352-2310(97)00101-5 (1997).

63. Lu, X. et al. Multivariate statistical analysis of heavy metals in street dust of Baoji, NW China. J. Hazard. Mater. 173, 744-749. https://doi.org/10.1016/j.jhazmat.2009.09.001 (2010).

64. Rajaram, B. S., Suryawanshi, P. V., Bhanarkar, A. D. \& Rao, C. V. C. Heavy metals contamination in road dust in Delhi city, India. Environ. Earth Sci. 72, 3929-3938. https://doi.org/10.1007/s12665-014-3281-y (2014).

65. Arslan, H. Heavy metals in street dust in Bursa, Turkey. J. Trace Microprobe Tech. 19, 439-445. https://doi.org/10.1081/TMA-10010 5058 (2001).

66. Gray, C. W., McLaren, R. G. \& Roberts, A. H. Atmospheric accessions of heavy metals to some New Zealand pastoral soils. Sci. Total Environ. 305, 105-115. https://doi.org/10.1016/S0048-9697(02)00404-7 (2003).

67. Rawat, M., Ramanathan, A. L. \& Subramanian, V. Quantification and distribution of heavy metals from small-scale industrial areas of Kanpur city, India. J. Hazard. Mater. 172, 1145-1149. https://doi.org/10.1016/j.jhazmat.2009.07.115 (2009).

68. Kannel, P. R., Lee, S., Kanel, S. R. \& Khan, S. P. Chemometric application in classification and assessment of monitoring locations of an urban river system. Anal. Chim. Acta 582, 390-399. https://doi.org/10.1016/j.aca.2006.09.006 (2007).

69. Zupan, M., Einax, J. W., Kraft, J., Lobnik, F. \& Hudnik, V. Chemometric characterization of soil and plant pollution: Part 1: Multivariate data analysis and geostatistical determination of relationship and spatial structure of inorganic contaminants in soil. Environ. Sci. Pollut. Res. 7, 89-96. https://doi.org/10.1065/espr199910.008 (2000).

70. Hanif, N. et al. Geo-accumulation and enrichment of trace metals in sediments and their associated risks in the Chenab River, Pakistan. J. Geochem. Explor. 165, 62-70. https://doi.org/10.1016/j.gexplo.2016.02.006 (2016).

71. Banu, Z., Chowdhury, M. S. A., Hossain, M. D. \& Nakagami, K. I. Contamination and ecological risk assessment of heavy metal in the sediment of Turag River, Bangladesh: An index analysis approach. J. Water Resour. Protect. 5, 239-248. https://doi.org/10. 4236/jwarp.2013.52024 (2013).

72. Ali, B. N. M., Lin, C. Y., Cleophas, F., Abdullah, M. H. \& Musta, B. Assessment of heavy metals contamination in Mamut river sediments using sediment quality guidelines and geochemical indices. Environ. Monit. Assess. 187, 1-11. https://doi.org/10.1007/ s10661-014-4190-y (2015).

73. Resongles, E. et al. Persisting impact of historical mining activity to metal ( $\mathrm{Pb}, \mathrm{Zn}, \mathrm{Cd}, \mathrm{Tl}, \mathrm{Hg})$ and metalloid (As, Sb) enrichment in sediments of the Gardon River, Southern France. Sci. Total Environ. 481, 509-521. https://doi.org/10.1016/j.scitotenv.2014.02. 078 (2014).

74. Filgueiras, A. V., Lavilla, I. \& Bendicho, C. Evaluation of distribution, mobility and binding behaviour of heavy metals in surficial sediments of Louro River (Galicia, Spain) using chemometric analysis: A case study. Sci. Total Environ. 330, 115-129. https://doi. org/10.1016/j.scitotenv.2004.03.038 (2004). 
75. Cuong, D. T. et al. Heavy metal contamination in mangrove habitats of Singapore. Mar. Pollut. Bull. 50, 1732-1738. https://doi. org/10.1016/j.marpolbul.2005.09.007 (2005).

76. Hlavay, J., Jonas, K., Elek, S. \& Inczedy, J. Characterization of the particle size and the crystallinity of certain minerals by infrared spectrophotometry and other instrumental methods-I. Investigations on clay minerals. Clay Clay Miner. 25, 451-456 (1977).

77. White, J. L. Interpretation of infrared spectra of soil minerals. Soil Sci. 112, 22-31 (1971).

78. Chandrasekaran, A. et al. FT-IR spectroscopy investigation of soils fromYelagiri Hills, Tamil Nadu, India. Sciencia 4(2), 29-40 (2013).

\section{Author contributions}

Dr. A.C. wrote the main manuscript text. Mr. C.K.S.K. prepared the figures, tables, and references and AAS analysis. Mr. V.S. has constructed FT-IR graphs with Origin software and minerals. Mr. S.M. has a SED-EDS graph and analysis. Ms. A.T. has created XRD graphs using Origin and Minerals, with comparison table.

\section{Competing interests}

The authors declare no competing interests.

\section{Additional information}

Correspondence and requests for materials should be addressed to A.C.

Reprints and permissions information is available at www.nature.com/reprints.

Publisher's note Springer Nature remains neutral with regard to jurisdictional claims in published maps and institutional affiliations.

(c) (i) Open Access This article is licensed under a Creative Commons Attribution 4.0 International License, which permits use, sharing, adaptation, distribution and reproduction in any medium or format, as long as you give appropriate credit to the original author(s) and the source, provide a link to the Creative Commons licence, and indicate if changes were made. The images or other third party material in this article are included in the article's Creative Commons licence, unless indicated otherwise in a credit line to the material. If material is not included in the article's Creative Commons licence and your intended use is not permitted by statutory regulation or exceeds the permitted use, you will need to obtain permission directly from the copyright holder. To view a copy of this licence, visit http://creativecommons.org/licenses/by/4.0/.

(C) The Author(s) 2021 